\title{
Emission of harmful gases from animal production in Poland
}

\author{
Kamila Mazur • Kamil Roman (1) \\ Witold Jan Wardal · Kinga Borek · Jan Barwicki • \\ Marek Kierończyk
}

Received: 27 August 2020 / Accepted: 2 May 2021 / Published online: 17 May 2021

(C) The Author(s) 2021

\begin{abstract}
The aim of the study was to present the scale of greenhouse gas emissions from animal production, and to provide test results from different housing systems. In three free stall buildings, two with slurry in deep channels and one with cattle in cubicles staying on shallow litter concentration of ammonia and carbon dioxide were measured in summer season by using dedicated equipment from Industrial Scientific Research. Air exchange was calculated
\end{abstract}

Highlights

- A comparative analysis of the results available in the literature has shown and confirmed significant lower ammonia emissions when using litters than with no litter housing.

- In system with bedding twice lower level of air exchange rate than recommended by standards caused much high level of ammonia concentration and quite high ammonia emission, although lower than from housing without litter.

- Ammonia emission from cattle barn in the litter-free system was about twice as high as compared to available data from the literature, which could have been caused by the higher ventilation index in line with the values recommended in the standards for cattle breeding.

- The usefulness of the carbon dioxide balance method for estimating air exchange from loose housing barns with roof ridge ventilation was confirmed.

K. Mazur · W. J. Wardal · K. Borek · J. Barwicki ·

M. Kierończyk

Institute of Technology and Life Sciences, Branch

in Warsaw, Warsaw, Poland

e-mail: k.mazur@itp.edu.pl on the base of balance carbon dioxide method. This method was used in order to estimate the air flow rate. Concentrations of ammonia and $\mathrm{CO}_{2}$ were measured as the base for air exchange and ammonia emission rates. Ammonia emissions were product of ammonia concentration and air exchange rate. Temperature and relative humidity were measured to establish microclimate conditions in buildings tested to show the overall microclimatic situation in buildings. Differences between ammonia emission rates were observed in both housing systems. The highest ammonia emission rate was equal to $2.75 \mathrm{~g} \cdot \mathrm{h}^{-1} \cdot \mathrm{LU}^{-1}$ in well-ventilated cattle barn with the largest herd size.

Keywords Emissions - Ammonia $\cdot$ Natural ventilation $\cdot$ Air exchange

W. J. Wardal

e-mail:w.wardal@itp.edu.pl

K. Borek

e-mail: k.borek@itp.edu.pl

J. Barwicki

e-mail: j.barwicki@itp.edu.pl

M. Kierończyk

e-mail: m.kieronczyk@itp.edu.pl

K. Roman $(\bowtie)$

Institute of Wood Sciences and Furniture, Warsaw

University of Life Sciences, Warsaw, Poland

e-mail:kamil_roman@sggw.edu.pl 
Table 1 Results of model analysis of typical dairy farms with feed production on the farm

Source: own elaboration based on Gridnev et al. (2014)

\begin{tabular}{|c|c|c|c|c|}
\hline Housing system & Tied-up & $\begin{array}{l}\text { Tied-up (2nd } \\
\text { type) }\end{array}$ & Free stall & $\begin{array}{l}\text { Free stall } \\
\text { (2nd } \\
\text { type) }\end{array}$ \\
\hline \multirow[t]{2}{*}{ Basic herd size cattle } & 100 & 100 & 200 & 200 \\
\hline & 142 & 142 & 284 & 284 \\
\hline Milk yield, 1 & 5000 & 5000 & 6000 & 6000 \\
\hline $\mathrm{CH}_{4}$ losses $\left(\right.$ eq. $\left.\mathrm{CO}_{2}\right), \mathrm{t}$ & 344.5 & 347.8 & 834.4 & 819.9 \\
\hline Emission $\mathrm{CH}_{4} \bullet \mathrm{kg} \bullet$ cow $\bullet$ year ${ }^{-1}$ & 4.05 & 4.16 & 4.65 & 4.84 \\
\hline $\mathrm{N}_{2} \mathrm{O}$ losses (eq. $\mathrm{CO}_{2}$ ), $\mathrm{t}$ & 663.0 & 645.3 & 1500.7 & 1329.0 \\
\hline
\end{tabular}

\section{Introduction}

Milk and meat production are finally balanced with an environmental and animal welfare conditions to minimize negative influence for the environment. Major amount of nitrogen are leaching from livestock production to the environment.

According to the inventories, agriculture is a significant source of greenhouse gases (GHG) (Roman et al., 2019). In 2015, the EU agricultural sector emitted $3751 \mathrm{kt}$ of ammonia and was responsible for 94\% of total ammonia emissions (Crippa et al., 2018; EUROSTAT, 2020). Poland is one of the most important contributors to nitrogen atmospheric emissions in the Baltic Sea Region (EUROSTAT, 2020).

Moreover, significant amounts of harmful ammonia gas are derived from livestock production. Cattle are responsible for $70 \%$ of total greenhouse gas emissions (Philippe \& Nicks, 2015).

There is a lack of data about ammonia emissions from cattle barns from central Europe. Ammonia emissions differ depending on climate zone, housing system, manure management (Baldini et al., 2016), type of feed (Bougouin et al., 2016) and animal breed.

Air temperature in the barn is the most important factor affecting ammonia emissions (Sanchis et al., 2019). Literature analysis shows that authors from across Europe describe the problem of harmful gases in connection with animal production. We have some works from Poland Herbut and Angrecka (2014) and Pietrzak (2006) —and abroad-Demmers et al. (1998), Dore et al. (2004), Jungbluth et al. (2001), Mohn et al. (2018) and Poteko et al. (2019).
Tied-up cattle barns were under observation using measurements of ventilation rate and concentration of harmful ammonia gas (Karłowski et al., 2008). The measurements were carried out of ammonia emissions from manure plate by using micrometeorological passive dosimetry method (Ferm et al., 2005; Marcinkowski, 2010).

There were prepared by Russian scientists' table of harmful gas emissions, including methane and forms of nitrogen from different cattle housing systems in intensive production in cold climate (Gridnev et al., 2014) (Table 1).

Ammonia emissions from systems with natural ventilation depend heavily on the efficiency of the ventilation system; the more effective it is, the greater the probability of higher emissions. Bougouin described negative impact of milk production on $\mathrm{NH}_{3}$ emission that milk yield had on $\mathrm{NH}_{3}$ emissions (Bougouin et al., 2016).

Demmers indicates that the $\mathrm{CO}_{2}$ balance method demands not only the presence of animals inside the building but also detailed knowledge about $\mathrm{CO}_{2}$ quantities. According to this information, carbon oxide could be a better tracer gas because of its features: its density is almost the same as the air and it can be measured by continuously working data analyzer, and is inertive enough and has low background concentration.

Table 2 shows the amounts of chosen GHG emissions according to Krawczyk and Walczak (2010). There were balance chambers used with steady thermal-humidity conditions and a steady air exchange rate. In this work, ammonia emissions tested from cattle barns with slurry and with solid manure in shallow boxes were presented. 
Table 2 Gaseous emissions from housing systems of technological groups $\left(\mathrm{kg} \mathrm{year}^{-1} \cdot \mathrm{LU}^{-1}\right)$

\begin{tabular}{|c|c|c|c|c|c|c|}
\hline & \multicolumn{6}{|l|}{ Housing system } \\
\hline & Littered straw & Littered sawdust & Deep litter straw & Deep litter sawdust & Without litter & Slotted \\
\hline \multicolumn{7}{|l|}{ Dairy cows } \\
\hline Water vapor & 3456.4 & 3562.1 & 3732.6 & 3862.8 & 3956.4 & $\mathrm{x}$ \\
\hline Carbon dioxide & 2664.8 & 2545.3 & 2989.4 & 2844.1 & 2764.8 & $\mathrm{x}$ \\
\hline $\mathrm{CH}_{4}$ & 108.4 & 112.91 & 123.53 & 126.32 & 119.2 & $\mathrm{x}$ \\
\hline $\mathrm{N}_{2} \mathrm{O}$ & 0.032 & 0.045 & 0.062 & 0.073 & 0.416 & $\mathrm{x}$ \\
\hline \multicolumn{7}{|l|}{ Heifers } \\
\hline Water vapor & 3110.4 & 3456.1 & 3567.1 & 3595.9 & 3645.2 & 3723.7 \\
\hline Carbon dioxide & 1944.6 & 1823.8 & 2078.3 & 1924.5 & 1998.2 & 2129.7 \\
\hline $\mathrm{CH}_{4}$ & 56.3 & 57.4 & 79.32 & 84.27 & 66.73 & 67.58 \\
\hline $\mathrm{N}_{2} \mathrm{O}$ & 0.01 & 0.016 & 0.019 & 0.021 & 0.022 & 0.024 \\
\hline \multicolumn{7}{|l|}{ Calves } \\
\hline Water vapor & $\mathrm{x}$ & $\mathrm{x}$ & 1941.43 & 2059.2 & $X$ & 2178.4 \\
\hline Carbon dioxide & $\mathrm{x}$ & $\mathrm{x}$ & 1108.23 & 1046.3 & $\mathrm{x}$ & 987.8 \\
\hline $\mathrm{CH}_{4}$ & $\mathrm{x}$ & $\mathrm{x}$ & 21.2 & 24.47 & $\mathrm{x}$ & 19.6 \\
\hline $\mathrm{N}_{2} \mathrm{O}$ & $\mathrm{x}$ & $\mathrm{x}$ & 0.002 & 0.004 & $\mathrm{x}$ & 0.006 \\
\hline
\end{tabular}

Source: own elaboration based on Krawczyk and Walczak (2010)

\section{Methods}

Determination of emissions from buildings with natural ventilation demands measurements of gas concentrations and air exchange rates. Also, CFD methods are available for ammonia emission modelling, but they still need to develop (Bjerg et al., 2013a, b; Yi Q et al., 2019a, b). In this study, levels of ammonia and carbon dioxide concentrations were tested both inside and outside the 3 boxed livestock buildings: one with shallow litter and two with slurry in deep channels.

Both gas concentration and air exchange rate should be measured, especially for naturally ventilated livestock buildings as determination of it is problematic. In such cases, tracer gas methods are used (as a type of balance method). Nosek et al. (2020) confirmed that tracer gas method is very useful for ventilation rate estimation.

For example, some researchers used $\mathrm{CO}_{2}, \mathrm{SF} 6$ or cryptone 85 as tracer gases (Müller et al. 2007; Kiwan et al., 2012).

Edouard et al. (2016) used tracer gas method as well as moisture balance method. Indicators of $\mathrm{CO}_{2}$ emissions by livestock animals and water vapor are not constant and depend on the animals, age and diet. In our study, the $\mathrm{CO}_{2}$ balance method was used.
The methods in our research consisted of the following stages:

(1) Measurements of ammonia concentrations in few points inside cattle barns (S) by using gas concentration meters, made by company Industrial Scientific Co.

(2) Estimation of air exchange rate ( $V$ ) using validated method of carbon dioxide balance. For metabolic emission of carbon dioxide by one LU, average values were used $\mathrm{W}_{\mathrm{CO} 2}=220 \mathrm{~g} \cdot \mathrm{h}^{-1} \cdot \mathrm{LU}^{-1}$ according to the Institute of Zootechnics in Cracow.

(3) Calculation of ammonia emission (E).

Ammonia emission $(E)$ was equal product of air exchange rate $(V)$ and ammonia concentration $(S)$ :

$E=V \cdot S$

where:

$E$-ammonia emission from building $\left[\mathrm{g} \cdot \mathrm{h}^{-1} \cdot \mathrm{LU}^{-1}\right]$,

$V$ - air exchange rate in building $\left[\mathrm{m}^{3} \cdot \mathrm{h}^{-1} \cdot \mathrm{LU}^{-1}\right]$,

$S$-average ammonia concentration from measurement points, reduced by the concentration of this gas in the air flowing into the cattle barn [ppm, converted into $\mathrm{g} \mathrm{m}^{-3}$ ]. 
The ventilation rate was calculated using the carbon dioxide balance method from the equation:

$V=\frac{\mathrm{WCO}_{2}}{C_{\text {inside }}-C_{\text {outside }}}\left[\mathrm{m}^{3} \cdot \mathrm{h}^{-1}\right]$

where:

$V$-air exchange rate in building $\left[\mathrm{m}^{3} \cdot \mathrm{h}^{-1} \cdot \mathrm{LU}^{-1}\right]$,

$\mathrm{W}_{\mathrm{CO} 2}$ - metabolic emission of carbon dioxide by one LU $\left[\mathrm{g} \cdot \mathrm{h}^{-1} \cdot \mathrm{LU}^{-1}\right]$,

$C_{\text {inside }}$-average $\mathrm{CO}_{2}$ concentration inside cattle barn-average from measurement points measured in particular time $\left[\mathrm{ppm}\right.$, converted into $\mathrm{g} \cdot \mathrm{m}^{-3}$ ],

$C_{\text {outside }}$-average $\mathrm{CO}_{2}$ concentration in air inflowing into the building [ppm, converted into $\mathrm{g}$ $\mathrm{m}^{-3}$.

Finally, ammonia emission was equal:

$E=\frac{\mathrm{WCO}_{2}}{C_{\text {inside }}-C_{\text {outside }}} \cdot S$

where:

$E$ - ammonia emission from building $\left[\mathrm{g} \cdot \mathrm{h}^{-1} \cdot \mathrm{LU}^{-1}\right]$; other marks supra.

Additionally, temperature and relative humidity were measured using thermo-hygrometers.

The following measurement equipment was used:

- 4 multi-gas monitors for $\mathrm{CO}_{2}$ and $\mathrm{NH}_{3}$ concentrations. They were mobile, with own memories, type MX6, American producer Industrial Scientific,
- 4 thermo-hygrometers LB-710 (TH-5, TH-6, TH-7, TH-8), connected with concentrator LB-731 for data collecting.

\section{Results}

A short characteristic of herd like herd size and system of removing manure is shown in Table 3. The annual milk yield was at the range from 7000 to 95001 in the extra class for cows Holstein-Friesian breed. In two boxed cattle barns with slatted floors, the slurry was collected in deep manure channels and pumped out from them. Additionally, robotic manure scrapers were regularly removing the slurry from slatted floors making them more clear. In all buildings, natural light was from the windows in the walls and from roof ridge gap. Table 4 presents the statistical values of ventilation rates (air exchange rates) and estimated diurnal average ammonia emissions from cattle barns tested during the summer period (June-July). Temperature and air relative humidity were measured separately.

The obtained results of harmful gas emission which is ammonia depend on the effectiveness of the ventilation.

The highest level of ammonia emission was observed from cattle barn with deep slurry channels and with the highest ventilation rate which amounted $2.75\left(\mathrm{~g} \cdot \mathrm{h}^{-1} \cdot \mathrm{LU}^{-1}\right)$. In contrary, the lowest emission

Table 3 General characteristics of tested objects

\begin{tabular}{|c|c|c|c|c|c|c|}
\hline No & $\mathrm{LU}$ & Housing type & Ventilation system & Unitary cubage & $\begin{array}{l}\text { Average milk } \\
\text { yield of herd; } \\
\text { litres } \bullet \text { cow }^{-1} \text { year }^{-1}\end{array}$ & Manure removing system \\
\hline 3 & 50 & $\begin{array}{l}\text { Free stall boxed, shallow } \\
\text { litter (straw), solid } \\
\text { floor }\end{array}$ & $\begin{array}{l}\text { Gravitational ventila- } \\
\text { tion, air inflow through } \\
\text { wall openings; outflow } \\
\text { through roof ridge gap }\end{array}$ & 107.8 & 7000 & $\begin{array}{l}2 \mathrm{~kg} \text { of straw per } 1 \mathrm{LU}, \\
\text { littered daily; hydraulic } \\
\text { manure scrapers, twice } \\
\text { a day }\end{array}$ \\
\hline 2 & 140 & $\begin{array}{l}\text { Free stall, boxed, with- } \\
\text { out litter }\end{array}$ & $\begin{array}{l}\text { Gravitational ventilation, } \\
\text { air inflow through wall } \\
\text { openings-mobile cur- } \\
\text { tains; outflow through } \\
\text { roof ridge gap }\end{array}$ & 70.64 & 8500 & $\begin{array}{l}\text { Slurry in deep channels; } \\
\text { robotic manure scraper } \\
5 \text { times per day }\end{array}$ \\
\hline 3 & 83 & $\begin{array}{l}\text { Free stall, boxed, with- } \\
\text { out litter, slatted floor }\end{array}$ & $\begin{array}{l}\text { Gravitational ventila- } \\
\text { tion, air inflow through } \\
\text { wall openings; outflow } \\
\text { through roof ridge gap }\end{array}$ & 74.00 & 9500 & $\begin{array}{l}\text { Robotic manure scraper } 3 \\
\text { times per day }\end{array}$ \\
\hline
\end{tabular}

Source: own study 
Table 4 Gaseous emissions from housing systems of objects tested $\left(\mathrm{kg} \cdot \mathrm{year}{ }^{-1} \cdot \mathrm{LU}^{-1}\right)$

\begin{tabular}{|c|c|c|c|c|c|c|c|c|}
\hline \multirow[t]{2}{*}{$\begin{array}{l}\text { No. of cow- } \\
\text { shed }\end{array}$} & \multirow[t]{2}{*}{$\begin{array}{l}\text { Statistical } \\
\text { value }\end{array}$} & \multirow[t]{2}{*}{$\begin{array}{l}\text { Temperature } \\
\text { inside } \\
{\left[{ }^{\circ} \mathrm{C}\right]}\end{array}$} & \multirow[t]{2}{*}{$\begin{array}{l}\text { Relative } \\
\text { humidity } \\
\text { outside } \\
{[\%]}\end{array}$} & \multirow[t]{2}{*}{$\begin{array}{l}\text { Relative } \\
\text { humidity } \\
\text { inside } \\
{[\%]}\end{array}$} & \multirow[t]{2}{*}{$\begin{array}{l}\text { Air exchange } \\
\text { rate }(\mathrm{V}) \\
{\left[\mathrm{m}^{3} \cdot \mathrm{h}^{-1} \cdot \mathrm{LU}^{-1}\right]}\end{array}$} & \multirow[t]{2}{*}{$\begin{array}{l}\mathrm{NH}_{3} \\
{[\mathrm{ppm}]}\end{array}$} & \multirow[t]{2}{*}{$\begin{array}{l}\mathrm{NH}_{3} \text { emis- } \\
\text { sion* } \\
\left.\mathrm{g} \cdot \mathrm{h}^{-1} \cdot \mathrm{LU}^{-1}\right]\end{array}$} & \multirow[t]{2}{*}{$\begin{array}{l}\mathrm{CO}_{2} \\
{[\mathrm{ppm}]}\end{array}$} \\
\hline & & & & & & & & \\
\hline \multirow[t]{3}{*}{1} & Mean & 23.92 & 73.86 & 73.3 & $262.2 / 203.2 *$ & $5.22 / 11.31^{*}$ & $1.73 / 2.64 *$ & $792 / 1132 *$ \\
\hline & Min & 19.53 & 38.64 & 52.12 & $160 / 84.9$ & $1 / 2 *$ & $0.2 / 0.27^{*}$ & $300 / 500^{*}$ \\
\hline & Max & 27.3 & 96.7 & 87.4 & $3653.5 / 1826.7 *$ & $17 / 18^{*}$ & $3.6 / 37.03 *$ & $500 / 1733 *$ \\
\hline \multirow[t]{3}{*}{2} & Mean & 23.69 & 48.14 & 58.31 & 401.76 & 11.97 & 2.75 & 845.5 \\
\hline & Min & 18.59 & 18.4 & 21.28 & 170.4 & 1 & 0.78 & 450 \\
\hline & Max & 30.61 & 67.65 & 77.34 & 3784.3 & 23 & 3.73 & 1380 \\
\hline \multirow[t]{3}{*}{3} & Mean & 17.72 & 59.25 & 69.32 & 399.65 & 6.16 & 1.47 & 665 \\
\hline & Min & 11.94 & 38.15 & 56.54 & 167.59 & 1 & 0.59 & 300 \\
\hline & Max & 21.85 & 95.13 & 90.21 & 3687.1 & 19 & 6.95 & 1500 \\
\hline \multicolumn{2}{|c|}{$\begin{array}{l}\text { Recommendation } \\
\text { (Collective work 2005) }\end{array}$} & $\begin{array}{l}\text { Optimal } \\
8-16\end{array}$ & - & $\begin{array}{l}\text { Optimal } 70 \\
\max .80\end{array}$ & 450 & Max. 20 & & Max. 3000 \\
\hline
\end{tabular}

*Day/night, source: own study

$1.47\left(\mathrm{~g} \cdot \mathrm{h}^{-1} \cdot \mathrm{LU}^{-1}\right)$ was observed in a cattle barn with the lowest cubage.

According to the above-presented table, the values of $\mathrm{NH}_{3}$ and $\mathrm{CO}_{2}$ emission levels were estimated. The established high, average and low levels of gas emissions were created, as multiple values of $7 \mathrm{ppm}$ for $\mathrm{NH}_{3}$ and $1000 \mathrm{ppm}$ for $\mathrm{CO}_{2}$. Created levels were dependent on the recommended limits of $\mathrm{NH}_{3}$ that equal $20 \mathrm{ppm}$ and $\mathrm{CO}_{2}$ equal $3000 \mathrm{ppm}$. Using the estimated levels, correlation of environmental parameters in reference to the gas emissions from cattle houses was conducted. The ANOVA method was chosen as a tool for statistical analysis. During the

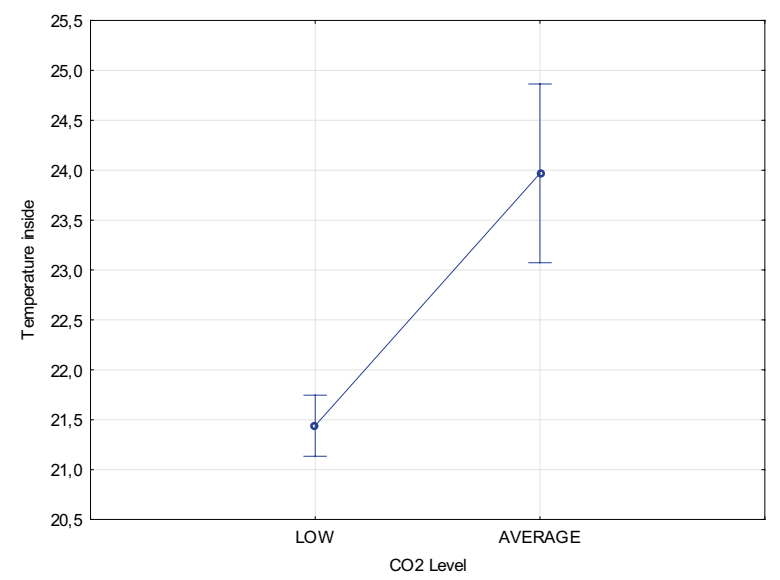

statistical analysis, the temperature inside, relative humidity outside and humidity inside were correlated to the gas emissions. The results of temperature compared with the $\mathrm{CO}_{2}$ and $\mathrm{NH}_{3}$ levels were presented in Fig. 1.

During the statistical analysis, the expected marginal mean of temperature influence to $\mathrm{CO}_{2}$ and $\mathrm{NH}_{3}$ emission density was specified. In the case of temperature impact on the $\mathrm{CO}_{2}$ emission level, the significance value $(p)$ was below than critical level of $0.05(5 \%)$, and the statistical empirical value $F(1$, $846)=27.494$. The statistical analysis of the temperature influencing the $\mathrm{NH}_{3}$ emission level delivers that

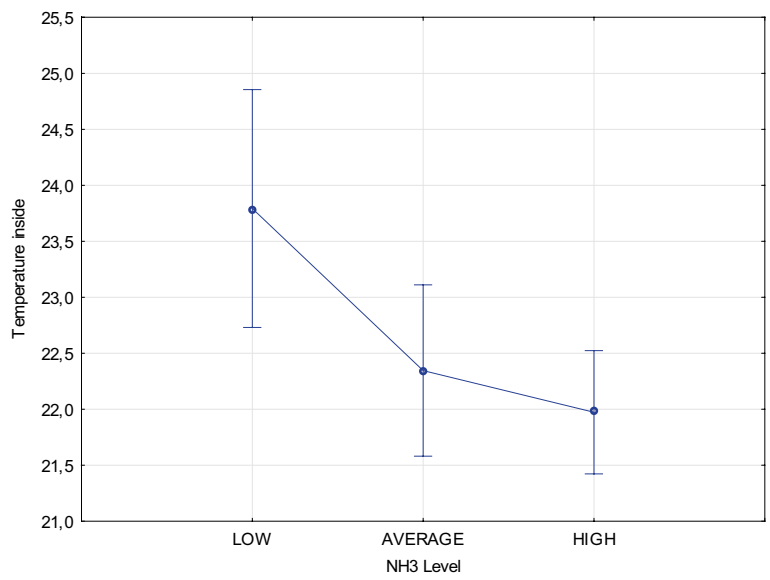

Fig. 1 The results of temperature comparison concerning $\mathrm{CO}_{2}$ and $\mathrm{NH}_{3}$ levels. Source: own study 

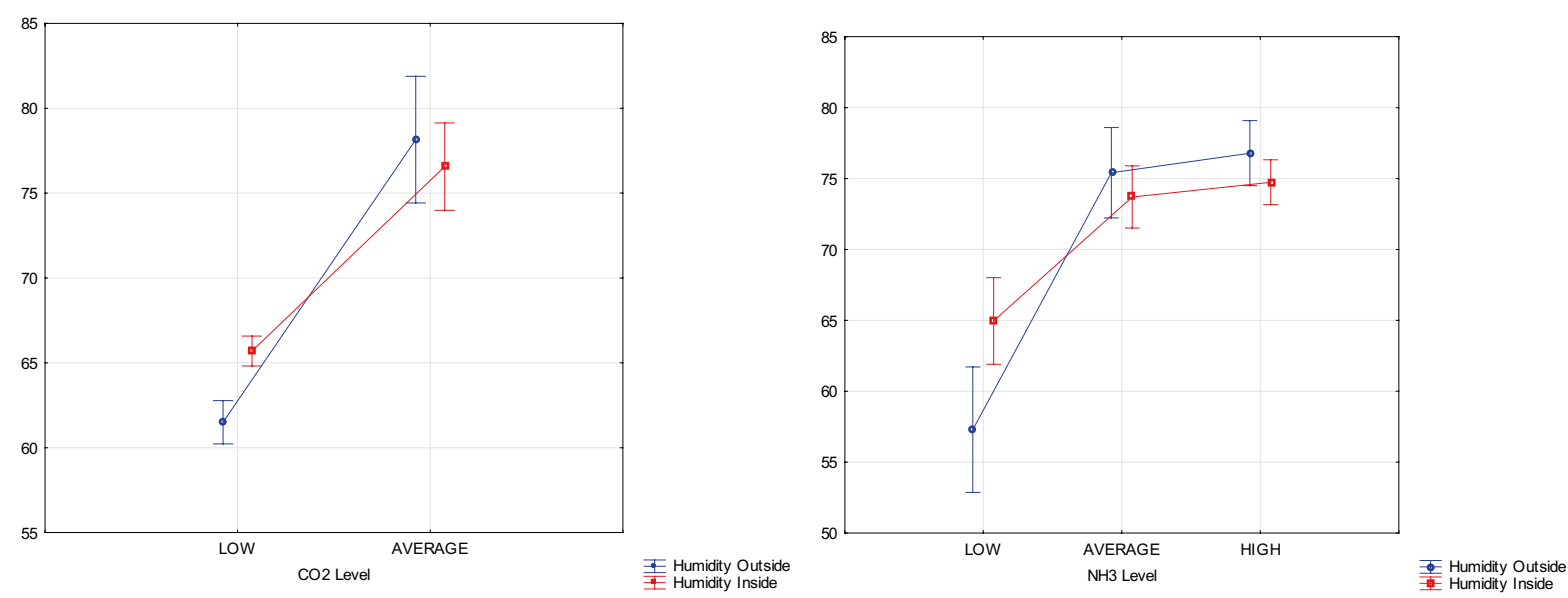

Fig. 2 The results of relative humidity outside and relative humidity inside comparison with the $\mathrm{CO}_{2}$ and $\mathrm{NH}_{3}$ levels. Source: own study

the significance level $(p)$ was 0.01184 and the statistical empirical value $F(2,846)=4.4595$. The case of temperature impact on the $\mathrm{CO}_{2}$ emission level, inversely than the $\mathrm{NH}_{3}$ emission level, delivers the correlation. The obtained results were the basis for the Duncan tests that determine the temperature values to homogeneous groups. The analysis showed that each of the tested temperatures is in a different homogeneous group, which makes significant differences in the temperature impact on the level of $\mathrm{CO}_{2}$ emissions. The mean temperature for the low level of the $\mathrm{CO}_{2}$ emission was $21.5^{\circ} \mathrm{C}$, for the average level was close to the $23.2{ }^{\circ} \mathrm{C}$, but high emission was not known. The correlation of relative humidity outside and relative humidity inside with the $\mathrm{NH}_{3}$ emissions from cattle houses was conducted. The estimated recommended levels of $\mathrm{NH}_{3}$ emissions were also used. The results of relative humidity outside and humidity inside correlation with the $\mathrm{CO}_{2}$ and $\mathrm{NH}_{3}$ levels were presented in Fig. 2.

It was statistically confirmed that the relative humidity outside and relative humidity inside had an influence on the $\mathrm{CO}_{2}$ and $\mathrm{NH}_{3}$ emission levels in both cases. Similarly, in both statistical analyses, the significance value $(p)$ was below a critical level, which means that the correlation exists. The empirical value of statistics $F(2,845)$ during the relative humidity outside and relative humidity inside comparison with the $\mathrm{CO}_{2}$ was equal to 34.726, and the Wilks Lambs $=0.92405$. In the case where the relative humidity outside and relative humidity inside were correlated with $\mathrm{NH}_{3}$, the empirical value of statistics $F(4,1690)=17.507$ and the Wilks Lambs $=0.92201$. The characteristics of homogeneous groups defining the effect of relative humidity outside and relative humidity inside comparison with the $\mathrm{CO}_{2}$ and $\mathrm{NH}_{3}$ levels were presented in Table 5.

According to Table 6, the increase of relative humidity outside and relative humidity inside caused the increase of $\mathrm{CO}_{2}$ and $\mathrm{NH}_{3}$ emission. Statistical analysis confirmed the need for reducing the relative humidity inside to limit the $\mathrm{CO}_{2}$ and $\mathrm{NH}_{3}$ emissions. Considering the whole scope of the conducted studies, it can be noticed that the best conditions for limiting $\mathrm{CO}_{2}$ are to reduce temperature and humidity

Table 5 Characteristics of homogeneous groups defining the effect of relative humidity outside and relative humidity inside comparison with the $\mathrm{CO}_{2}$ and $\mathrm{NH}_{3}$ levels

\begin{tabular}{|c|c|c|c|c|}
\hline \multirow{3}{*}{$\begin{array}{l}\text { Emission } \\
\text { level }\end{array}$} & \multicolumn{2}{|l|}{$\mathrm{CO}_{2}$} & \multicolumn{2}{|l|}{$\mathrm{NH}_{3}$} \\
\hline & $\begin{array}{l}\text { Mean of } \\
\text { relative } \\
\text { humidity } \\
\text { outside }\end{array}$ & $\begin{array}{l}\text { Mean of } \\
\text { relative } \\
\text { humidity } \\
\text { inside }\end{array}$ & $\begin{array}{l}\text { Mean of } \\
\text { relative } \\
\text { humidity } \\
\text { outside }\end{array}$ & $\begin{array}{l}\text { Mean of } \\
\text { relative } \\
\text { humidity } \\
\text { inside }\end{array}$ \\
\hline & $\%$ & & & \\
\hline Low & $60.9^{\mathrm{a}}$ & $64.1^{\mathrm{a}}$ & $58.5^{\mathrm{a}}$ & $60.6^{\mathrm{a}}$ \\
\hline Average & $86.5^{\mathrm{b}}$ & $78.9^{\mathrm{b}}$ & $66.4^{\mathrm{b}}$ & $68.8^{\mathrm{b}}$ \\
\hline High & - & - & $73.1^{\mathrm{c}}$ & $73.4^{\mathrm{c}}$ \\
\hline
\end{tabular}


Table 6 Air exchange rates in cattle barns according to Polish standards

\begin{tabular}{lc}
\hline Summer & Winter \\
\hline $350-400 \mathrm{~m}^{3} \cdot \mathrm{h}^{-1}$ for dairy cows & $90 \mathrm{~m}^{3} \cdot \mathrm{h}^{-1}$ \\
For cows with higher milk yield, it should be & Deep litter- \\
increased by $25 \%$ & increase by \\
& $50 \%$ \\
\hline
\end{tabular}

Source: own elaboration based on Collective work (2005)

outside and inside of livestock housing. Ammonia emission could be reduced by simultaneously decreasing air humidity and decreasing air temperature. In the case of $\mathrm{NH}_{3}$ emission, reduction is necessary to increase the temperature and reduce the humidity inside the building.

\section{Discussion}

Results derived from our emission experiments were common to other authors (Walczak and Krawczyk) despite weather conditions. In particular, in non-litter cowsheds, higher $\mathrm{NH}_{3}$ emissions were observed. A similar situation was described by Zhang who tested ammonia emissions from 11 types of cattle barns, with different floor and manure removing systems and the highest emission was in non-littered cattle barns (Zhang et al., 2005).

Similar results were obtained by a Polish researcher, which calculated ammonia emissions by using model (not measured) from dairy cattle for particular technologies ranging from 6.4 per year for deep litter up to $28.69 \mathrm{~kg}$ per year for a slurry system, but these results based only on simply assuming fixed rate of nitrogen losses from manure in livestock buildings (Pietrzak, 2006).

Mosquera et al. (2005) stated that from barns with deep litter, an average ammonia emission was at the level of $13.9 \mathrm{~kg}$ per cow and year. It is known from other research tests that ammonia emission from cattle barn with the solid floor was about 50\% lower than emission from buildings with the slatted floor (Swierstra et al., 1995). In contrast, research conducted by Baldini shows higher emission factors in cubicles covered with straw (Baldini et al., 2016).

Also, differences of $\mathrm{NH}_{3}$ emissions observed between tied and loose housing were observed by Poteko et al. (2019). A mechanical ventilation system was used and ammonia concentration was measured 10 times per hour from exhaust air. In experiments, single data was as average value from measurements during summer season. In our conducted tests for this article, the single result was based on the average from every 5 min during a couple of chosen, representative days in the summer period.

Jungbluth et al. (2001) were conducting $\mathrm{NH}_{3}, \mathrm{CO}_{2}$ and $\mathrm{CH}_{4}$ in respiratory chambers and in cattle barn for 50 cows with gravitational ventilation. In building, 27.8 to $50 \mathrm{~g} \cdot \mathrm{h}^{-1}$ per LU of ammonia emission was obtained. According to results obtained by Koerkamp et al. (1998), ammonia emission from boxed barns was at wide level 987-2001 $\mathrm{mg} \cdot \mathrm{h}^{-1}$ per animal.

There were ammonia emissions tested from beef and dairy cattle barns, and the following results are obtained by Demmers: from a system with slurry, $3.7 \mathrm{~kg}$ during 190 days of being inside livestock buildings for beef cattle, and $6 \mathrm{~kg}$ during 190 days of being inside livestock buildings for dairy cattle (both indicators based per $500 \mathrm{~kg}$ of live weight) (Demmers et al., 1998).

In our research, we obtained higher emissions from all object tested (with bedding and without bedding) compared to other authors' results.

Table 6 shows the recommended values of the air exchange rate in buildings for cattle in Poland. Only one of the cattle barns tested had ventilation rate below the recommended values.

According to Demmers et al. (1998), the annual $\mathrm{NH}_{3}$ emission from litter-free barns was about two times higher than emission from barns with litter. A similar trend was obtained in our research, where the emission from the litter-free system in one of the barns was about $24 \mathrm{~kg} \cdot \mathrm{year}^{-1} \cdot \mathrm{LU}^{-1}$ and for the litter system $12.87 \mathrm{~kg} \cdot \mathrm{year}^{-1} \cdot \mathrm{LU}^{-1}$.

\section{Conclusions}

Recently, livestock production significantly increased in Central Europe that involved the need of correction of emission factors. Generally, in Poland, it is utilized emission coefficient elaborated in Northern European countries (UK, DK and NL). In this study, first step was made to present Polish emission factor dedicated especially to summer season conditions.

Although the change of temperature and humidity was not huge, measured values allowed estimating the 
levels of gas emission in order to carry out the statistical analysis. According to the study, the increase of relative humidity outside and relative humidity inside caused an increase of $\mathrm{CO}_{2}$ and $\mathrm{NH}_{3}$ emission. A completely different validity occurred in accordance to the measured temperature values, where the increase in temperature could cause the reduction of $\mathrm{NH}_{3}$ emission. However, this validity was not confirmed by statistical analysis where the lack of temperature influence on the $\mathrm{NH}_{3}$ emission level confirms the value significance level $p=0.01184$. All other cases of statistical analysis have reached the significance value $p$ below the critical level of 0.05 . The main conclusion from the research is that ammonia emissions from cattle barns with slurry were higher than from cattle barn bedded with straw, but simultaneously in the night period, both emission levels were comparable.

Data availability Due to confidentiality agreements, supporting data can only be made available to bona fide researchers subject to a non-disclosure agreement. Details of the data and how to request access are available from Kamil Roman at Warsaw University of Life Sciences WULS.

Open Access This article is licensed under a Creative Commons Attribution 4.0 International License, which permits use, sharing, adaptation, distribution and reproduction in any medium or format, as long as you give appropriate credit to the original author(s) and the source, provide a link to the Creative Commons licence, and indicate if changes were made. The images or other third party material in this article are included in the article's Creative Commons licence, unless indicated otherwise in a credit line to the material. If material is not included in the article's Creative Commons licence and your intended use is not permitted by statutory regulation or exceeds the permitted use, you will need to obtain permission directly from the copyright holder. To view a copy of this licence, visit http://creativecommons.org/licenses/by/4.0/.

\section{References}

Baldini, C., Borgonovo, F., Gardoni, D., \& Guarino, M. (2016). Comparison among $\mathrm{NH}_{3}$ and GHGs emissive patterns from different housing solutions of dairy farms. Atmospheric Environment, 141, 60-66. https://doi.org/10.1016/j. atmosenv.2016.06.047

Bjerg, B., Norton, T., Banhazi, T., Zhang, G., Bartzanas, T., Liberati, P., Cascone, G., Lee, I., \& Marucci, A. (2013a). Modelling of ammonia emissions from naturally ventilated livestock buildings. Part 1: Ammonia release modelling, Biosystems engineering, 116(3):232-245. https://doi. org/10.1016/j.biosystemseng.2013.08.001
Bjerg, B., Cascone, G., In-Bok, L., Bartzanas, T., Norton, T., Hong Se, W., Seo Il, H., Banhazi, T., Liberati, P., Marucci, A., \& Zhang, G. (2013b). Modelling of ammonia emissions from naturally ventilated livestock buildings. Part 3: CFD modelling. Biosystems engineering, 116(3):259275. https://doi.org/10.1016/j.biosystemseng.2013.06.012

Bougouin, A., Leytem, A., Dijkstra, J., Dungan, R. S., \& Kebreab, E. (2016). Nutritional and environmental effects on ammonia emissions from dairy cattle housing: A metaanalysis. Journal of Environmental Quality, 45, 1123. https://doi.org/10.2134/jeq2015.07.0389

Collective work (Domasiewicz T., Głaszczka A., Mazur K., Wardal W., Rudnik K., Winnicki S., Eymontt A., Rasmussen J.B., Nielsen L.A.H., Pedersen J.,Frederiksen J., Brikkjaer K.O., Jepsen L., Morsing S.) Housing systems for cattle. Handbook (2005). IBMER, Warsaw, Poland and DAAS, Skejby Denmark, pp.172.

Crippa, M., Guizzardi, D., Muntean, M., Schaaf, E., Dentener, F., van Aardenne, J. A., Monni, S., Doering, U., Olivier, J. G. J., Pagliari, V., \& Janssens-Maenhou, G. (2018). Gridded emissions of air pollutants for the period 19702012 within EDGAR v4.3.2 Earth System Science Data Discussions, https://doi.org/10.5194/essd-2018-31

Demmers, T. G. M., Burgess, L. R., Short, J. L., Phillips, V., Clark, J. A., \& Wathes, C. M. (1998). First experiences with methods to measure ammonia emissions from naturally ventilated cattle buildings in the U.K. Atmospheric Environment, 32(3): 285-293.

Dore, C. J., Jones, B. M. R., Scholtens, R. H., \& In't Veld, Burgess, J. R. L., \& Phillips, V. R. (2004). Measuring ammonia emission rates from livestock buildings and manure stores - part 2: Comparative demonstrations of three methods on the farm. Atmospheric Environment, 38(19), 3017-3024

Edouard, N., Mosquera, J., \& van Dooren, H. J. C. (2016). Comparison of $\mathrm{CO}_{2}$ and SF6-based tracer gas methods for the estimation of ventilation rates in a naturally ventilated dairy barn. Biosystems Engineering, 149, 11-23. https:// doi.org/10.1016/j.biosystemseng.2016.06.001

EUROSTAT. (2020). Ammonia emissions from agriculture ( EEA) https://ec.europa.eu/eurostat/tgm/refreshTableAction. do?tab $=$ table $\&$ plugin $=1 \&$ pcode $=$ sdg_02_60\&language $=$ en available on-line 5.06.2020

Ferm, M., Marcinkowski, T., Kieronczyk, M., \& Pietrzak, S. (2005). Measurements of ammonia emissions from manure storing and spreading stages in Polish commercial farms. Atmospheric Environment., 39(37), 7106-7113

Gridnev, P. I., Gridneva, T., Spotaru, J., Romaniuk, W. (2014). Влияние технологий производства молока на ущерб окружающей среды [The impact of technology on the milk production of environmental damage] Ed. W. Romaniuk. In: Проблемы интенсификации животноводства с учетом охраны окружаютей среды и производства альтернативных источников энергии, в том числе биогаза [Problems of animal production intensification with regard to environment protection and alternative energy production, including biogas]. Warszawa-Falenty. ISBN 978-83-62416-75-2, 84-94.

Herbut, P., \& Angrecka, S. (2014). Ammonia concentrations in a free-stall dairy barn. Annals Animal Science, 14(1), 153-166. https://doi.org/10.2478/aoas-2013-0065. 
Jungbluth, T., Brose, G., \& Hartung, E. (2001). Greenhouse gas emissions from animal houses and manure stores. Nutrient Cycling in Agroecosystems, 60, 133-145

Karłowski, J., Myczko, R., Kołodziejczyk, T., \& Kuczyński, T. (2008). Współczynniki emisji amoniaku i gazów cieplarnianych z obór z wentylacją mechaniczną. Problemy Inżynierii Rolniczej, 1(59):151-158 https://www. itp.edu.pl/wydawnictwo/pir/zeszyt_59_2008/karlowski_ wspolczynniki_p.pdf

Kiwan, A., Berg, W., Fiedler, M., Ammon, Ch., Gläser, M., Müller, H. J., \& Brunsch, R. (2012). Air exchange rate measurements in naturally ventilated dairy buildings using the tracer gas decay method with $85 \mathrm{Kr}$, compared to $\mathrm{CO}_{2}$ mass balance and discharge coefficient methods. Biosystems Engineering, 116(3), 286-296. https://doi.org/10. 1016/j.biosystemseng.2012.11.011

Koerkamp, G., Metz, J. H. M., Uenk, G. H., Philips, V. R., Holden, M. R., Sneath, R. W., \& Short, J. L. (1998). Concentration and emissions of ammonia in livestock buildings in Northern Europe. Journal of Agricultural Engineering Research, 70(1), 79-95

Krawczyk, W., \& Walczak, J. (2010). Potencjał biogenny obornika jako źródło emisji amoniaku i zagrożenia środowiska (Biogenic potential of manure as a source of ammonia emission and environmental threat). Roczniki Naukowe Zootechniki, 37(2):187-193. https://rnz.izoo. krakow.pl/files/RNZ_2010_37_2_art12.pdf

Marcinkowski, T. (2010). Emisja gazowych związków azotu z rolnictwa [The emission of gaseous nitrogen compounds from agriculture]. Woda-Środowisko - Obszary Wiejskie, 1/3(31):175-189.

Mohn, J., Zeyer, K., Keck, M., Keller, M., Zähner, M., Poteko, J., Emmenegger, L., \& Schrade, S. (2018). A dual tracer ratio method for comparative emission measurements in an experimental dairy housing. Atmospheric Environment 179, 12-22. https://doi.org/10.1016/j.atmosenv.2018.01.057

Mosquera, J., Monteny, G. J., \& Erisman, J. W. (2005). Overview and assessment of techniques to measure ammonia emissions from animal houses: the case of the Netherlands. Environmental Pollution, 135(3), 381-388. https:// doi.org/10.1016/j.envpol.2004.11.011

Müller, H. J., Möller, B., Gläser, M., \& Cespiva, M. (2007) Determination of ammonia emission from naturally ventilated animal houses. In: Monteny G. J., Hartung E. (Ed.), Ammonia emissions from agriculture. Wageningen. Germany. Potsdam. Praha. Czech Republic:359-360. https://www.scopus. $\mathrm{com} / \mathrm{record} /$ display.uri?eid=2-s2.0-84885062785\&origin= inward\&txGid=809ac40fb6a9824ae8f7cbdcca0632bf

Nosek, Š., Kluková, Z., Jakubcová, M., Yi, Q., Janke, D., Demeyer, P., Jaňour, Z. (2020). The impact of atmospheric boundary layer, opening configuration and presence of animals on the ventilation of a cattle barn. Journal of Wind Engineering and Industrial Aerodynamics, 201:104185. https://doi.org/10.1016/j.jweia.2020.104185
Philippe, F. X., \& Nicks, B. (2015). Review of greenhouse gas emissions from pig houses: Production of carbon dioxide, methane and nitrous oxide by animals and manure. Agriculture, Ecosystems \& Environment, 199(1), 10-25. https://doi. org/10.1016/j.agee.2014.08.015

Pietrzak, S. (2006). Metoda inwentaryzacji emisji amoniaku ze źródeł rolniczych w Polsce i jej praktyczne zastosowanie. Woda - Środowisko-Obszary Wiejskie 1(16):319-334 https://www.itp.edu.pl/wydawnictwo/woda/zeszyt_16_ 2006/artykuly/Pietrzak1.pdf

Poteko, J., Zähner, M., \& Schrade, S. (2019). Effects of housing system, floor type and temperature on ammonia and methane emissions from dairy farming: A meta-analysis. Biosystems Engineering, 182, 16-28. https://doi.org/10. 1016/j.biosystemseng.2019.03.012

Roman, M., Roman, K., \& Roman, M. (2019). Methods of estimating particulates emission in agriculture exemplified by animal husbandry. [in:]. Proceedings of the International Scientific Conference Hradec Economic Days. Published University of Hradec Kralove, Faculty of Informatics and Management, Hradec Kralove. 9(2), 260-268. https:// digilib.uhk.cz/bitstream/handle/20.500.12603/159/ ROMAN,\%20ROMAN,\%20ROMAN.pdf?sequence $=1$

Sanchis, E., Calvet, S., del Prado, A., \& Estellés, F. (2019). A meta-analysis of environmental factor effects on ammonia emissions from dairy cattle houses. Biosystems Engineering, 178, 176-183. https://doi.org/10.1016/j.biosystemseng. 2018.11.017

Swierstra, M., Smits, C. J., \& Kroodsma, W. (1995). Ammonia emission from cubicle houses for cattle with slatted and solid floors. Journal of Agricultural Engineering Research, 62(2), 127-132. https://doi.org/10.1006/jaer. 1995.1071

Yi, Q., Wang, X., Zhang, G., Li, H., Janke, D., \& Amon, T. (2019a). Assessing effects of wind speed and wind direction on discharge coefficient of sidewall opening in a dairy building model - A numerical study. Computers and Electronics in Agriculture, 162, 235-245. https://doi.org/10. 1016/j.compag.2019.04.016

Yi, Q., Li, H., Wang, X., Zong, Ch., \& Zhang, G. (2019b). Numerical investigation on the effects of building configuration on discharge coefficient for a cross-ventilated dairy building model. Biosystems Engineering, 182, 107-122. https://doi.org/10.1016/j.biosystemseng.2019.04.003

Zhang, G., Strøm, J. S., Li, B., Rom, H. B., Morsing, S., Dahl, P., \& Wang, C. (2005). Emission of ammonia and other contaminant gases from naturally ventilated dairy cattle buildings. Biosystems Engineering, 92(3), 355-364. https://doi.org/10.1016/j.biosystemseng.2005.08.002

Publisher's Note Springer Nature remains neutral with regard to jurisdictional claims in published maps and institutional affiliations. 